Carolina Cenobio Castillo, Josip A. Slisko', Lidia A. Hernández Rebollar, Adrián Corona Cruz

Facultad de Ciencias Físico Matemáticas, Benemérita Universidad Autónoma de Puebla, Puebla, México

\title{
A few considerations of climbing-snail problem: Fibonacci's error, problem's popularity and Mexican students' performances
}

\begin{abstract}
Climbing-snail problem is a popular problem in which people give erroneous solutions. We first give a short account of its interesting history. Distinguished mathematicians (Fibonacci, Calandri, Riess and some others) gave erroneous solutions, too! Then we provide an evidence of the problem's amazing popularity at puzzle websites, in puzzle books, mathematics textbooks and manuals for entrance exams. Being so, it is strange that there are a few studies that explored students' performances in solving climbing-snail problem. After these introductory considerations, we present a small-scale pilot study whose aim was to explore the influence of the correct answer positions on the students' performances in a paper-and-pencil task based on that problem. Two multiple-choice versions of the problem, with the correct answer as the first and the last choice, were given to two different-age groups of Mexican students $\left(N_{1}=68\right.$, when the correct answer was the first choice and $N_{2}=81$, when it was the last choice). The results suggest that students' solving performances were influenced by the age and the position of the correct answer. When the correct answer was the first choice, older students greatly outperformed younger students, but with the correct answer as the last choice, older students were only slightly better. Finally we comment the most common procedures used by students and formulate some implications of these results for mathematics teaching.
\end{abstract}

Key words: Climbing-snail problem, Fibonacci's error, mathematical problem solving, multiple-choice format, students' drawings, students' mathematical reasoning

1 jslisko@fcfm.buap.mx Copyright (C) 2016 by the authors, licensee Teacher Education Faculty University of Belgrade, SERBIA.

This is an open access article distributed under the terms of the Creative Commons Attribution License (CC BY 4.0) (https://creativecommons.org/licenses/by/4.0/), which permits unrestricted use, distribution, and reproduction in any medium, provided the original paper is accurately cited. 


\section{Introduction}

Enigmas and riddles are part of human culture since ancient times. Their popularity and long life reveal deep human obsession with mysterious and unknown layers of life and world (Danesi, 2002).In Greek mythology, the most famous enigma concerns Sphinx, the daughter of King Laius, a creature with wings, lion's body, face and chest of a woman. Sphinx controlled entry into the city of Thebes, devouring all people unable to respond to the following riddle:

What is it that walks on four legs in the morning, in the afternoon on two legs and, at the night, on 3 legs?

Oedipus solved the riddle with the answer "a man", because he craws in childhood, goes uprightly in adulthood and needs a stick in old age. Seeing her riddle solved, Sphinx fell into depression and killed herself, jumping off a high rock.

Over time, the riddles ceased to be the matter of life and death, becoming, together with jokes, dances and songs, a playful possibility for spending free time. While previously number amusements were inserted sporadically in mathematical books, the genre of "recreational mathematics" begins in 1612, with the book "Entertaining problems solved with numbers," written by the French mathematician Bachet. Throughout the four centuries, many books have been published, forming an impressive bibliography (Schaaf, 1955; Singmaster, 2004).

The difficulty of mathematical puzzles follows from the fact that humans use two different thinking systems when facing a problem. The "System 1" exercises routine and intuitive thinking, while the "System 2" performs critical and reflective thinking. The winner of the Nobel Prize in economics, Daniel Kahneman, calls these two types of thinking "fast thinking" and "slow thinking" (Kahneman, 2011). "Fast thinking" is intuitive, emotional, effortless and without conscious control. On the contrary, "slow thinking" is a controlled mental activity, effortful and open to the logical and complex considerations.

Good mathematical puzzles activate in many persons the "System 1" (fast thinking) that leads to an "obvious" but wrong answer. The correct answer can be obtained only by using the "System 2" (slow thinking), critically analyzing the fine details of the situation regarding the problem situation.

In 1998, Martin Gardner, the most famous promoter of mathematical games and puzzles, declared that recreational mathematics, although having enormous potential to motivate students to appreciate the beauty of mathematics, was not sufficiently present in the programs and textbooks used in mathematics education (Gardner, 1998).

Recently, it seems the situation might change due to two reasons. On one hand, recreational mathematics and puzzles allow teachers to explore a new mode of teaching problem solving (Averbach \& Chein, 2012) and mathematical modeling (Michalewicz \& Michalewicz, 2008; Meyeret al. 2014).

On other hand, mathematical puzzles entered the world of business and economy-related sciences. At Microsoft, Google and other high-tech companies, "human-like sphinxes" manage their demanding job interviews, requiring candidates to solve mathematical puzzles to demonstrate that they have the intelligence, imagination and ability to solve real-world problems (Poundstone, 2003; Poundstone, 20012). Unlike to unfortunate visitors to the city of Thebes, those who fail to solve the puzzles are not devoured, but surely lose the opportunity of a dreamed job.

Additionally, Professor of Yale University Shane Frederick has designed "Cognitive Reflection Test” (Frederick, 2005), putting together three wellknown mathematical puzzles:

(1) A bat and a ball cost $\$ 1.10$ in total. The bat costs $\$ 1.00$ more than the ball. How much does the ball cost? cents. (Fast answer: 10 cents; Slow answer: 5 cents) 
(2) If it takes 5 machines 5 minutes to make 5 widgets, how long would it take 100 machines to make 100 widgets? minutes. (Fast answer: 100 minutes; Slow answer: 5 minutes)

(3) In a lake, there is a patch of lily pads. Everyday, the patch doubles in size. If it takes 48 dayfor the patchto cover the entire lake, how longwould it take for the patch to cover half of the lake? days.(Fast answer: 24 days; Slow answer: 47 days)

Note: Fast and slow answers are not part of the test.

This simple test measures very well the propensity of people to use either fast (intuitive) thinking or slow (reflexive) thinking, when dealing with different decision-taking situations. It has been shown that the score on the test predicts with an amazing precision how a person makes (good or bad) decisions on various economy-related problems. In other words, knowing the performance of a person in the Cognitive Reflection Test, it is possible to foretell her or his likely economic behavior. For example, a lower cognitive ability is associated with greater risk aversion, and more pronounced impatience (Dohmen et al., 2010).

"Climbing-snail problem", that was the subject of our study, has numerous versions. For the reasons, that will be elaborated more later, here come as examples two Internet variants. The first was found on a Serbian and the second on a Croatian educational site:

1. "A pole has a height of 10 meters. Early in the morning, a snail heads toward to the top of the pole. During the day, it is able to climb up 3 meters, but during the night, while it has some rest, it slides back 2 meters. During which day will the snail reach the top of the pole?" (Kosanić, n.d.)

2. "A snail climbs a 10-meter high pole. During the day, it climbs $5 \mathrm{~m}$, and during the nights it goes down $4 \mathrm{~m}$. How many days it needs to get up to the top of the pole? (a) 6, (b) 7, (c) 8, (d) 9." (Matka, n. d.)
The "fast answer" in both formulations is "on the 10th day", based on an "obvious reasoning": Because during one day and one night the snail climbs 1 meter $(3 m-2 m=5 m-4 m=1 m)$, to climb 10 meters ten days and ten nights are needed. Due to different movement data, "slow answers" are different. In the first case, it is "on 8th day". Namely, after 7 days and 7 nights, the snail is at the height of 7 meters and during the eighth day it climbs up 3 missing meters to reach the top of the pole. In the second case, it is "on the $6^{\text {th }}$ day". During five days and nights, the snail is at the height of 5 meters and needs $6^{\text {th }}$ day to climb 5 missing meters to get on the top of the pole.

Most important difference is the following one: In the first case, the solver must provide her or his self-generated answer, while, in the second case, the solver has chance to select an answer among offered ones. Some research results show that students perform better in later than in former case (Dudaite, 2013).

It is important to note, that "fast thinking» answer "10» is not among multiple choices. As common erroneous answers play role of distractors, it is recommendable that, at least, one of them is an answer that studens are likely to self-generate following their own way to solve the problem. In this particular case, a better set of multiple choices would be: (a) 6; (b) 7; (c) 8; (d) 9; (e) 10. We will comment later about the influence of the position of the correct answer on the students' performances.

\section{Climbing-snail problem: a short historical comment}

It is not so widely known (but it surely should be!) that the fast-thinking students' answer was "professional answer» given by mathematicians in Middle Age to different formulations of climbing snail problem during a few centuries, for example, in Italy from early 13 th century to late 15 th century and in Germany even in early 16th century (Sing- 
master, 2004). Among those mathematicians was also Fibonacci, one of the best in the Middle Age. In his famous textbook «Liber abaci», written in 1202, he formulated the problem with a fictitious lion as the climbing animal:

"On the Lion Who Was in a Pit

A certain lion is in a certain pit, the depth of which is 50 palms, and he ascends daily $1 / 7$ of a palm, and descends $1 / 9$. It is sought in how many days will he leave the pit." (Sigler, 2002, p. 273)

Using the same fast-thinking approach, as today's many children and adults do, Fibonacci finds the difference between $1 / 7$ and $1 / 9$, obtaining $2 / 63$. After that he divides 50 with $2 / 63$ to get the wrong answer of 1,575 days. Nevertheless, slow-thinking answer is 1,572 days and 1,571 nights.

Calandri, in his book "De arithmetica" published in 1491, used the same context and numbers, but the climbing animal, instead of a lion, was a snake. His answer, 1,575 days, was erroneous, too.

German mathematician Adam Riese was the first to formulate, in 1518 , the problem with a snail as a climbing animal:

"A snail is a well at the depth of 32 cubits. Every day it climbs up $4 \frac{2}{3}$ cubits and every night it goes down $3 \frac{3}{4}$ cubits. After how many days it will get out?"(Deschauer, 2013, s. 107)

The first solution " $30 \frac{9}{11}$ days", found by Riese, was wrong (Sliško, 2016). In later editions of his book, starting with one published in 1525, Riese was able to get a correct solution " $30 \frac{27}{28}$ days", although by using an ad hoc and conceptually opaque arithmetic procedure (Sliško, 2016).

As introducing history of mathematics into teaching can inform students about about its realworld utility thrught use of thoughtfully-designed measuring instruments (Mass Esteve, 2014), above mentioned errors might be a base for creating problem-solving activities that give students an inspiring feeling that they are able to correct an error made in past by some famous matematicians (Sliško, 2016).

Error repetition, in the times of Fibonacci and Calandri, can be understood because a correct solution, taking into account problem's"boundary condion", was still unknown. Today, it seems almost incredible that someone would include an erroneous answer on that problemin a book related to mathematics. Nevertheless, an example of fast-thinking phenomenon connected with the snail problem appeared again in a recently published book "Games and mathematics. Subtle connections" (Wells, 2012). The book was written by David Wells, former Cambridge student, chess champion and prolific author of many popularization books on mathematics.

His formulation and "solution" goes as follows:

"Another traditional puzzle appeals to me because it sets the solver a trap, albeit a rather obvious one. Here is one version. A snail - or a serpent or a frog! - lies at the bottom of a well, 30 units deep. It climbs 6 units every day but falls back 3 units every night. How long does it take to escape from the well? The obvious answer is that the snail rises 3 units every day-and-night, on balance, so it takes 10 days-and-nights to escape, but this is wrong because it will actually treach the top of the well halfway through the 10 day and after only 9 nights." (Wells, 2012, p. 4)

The "logic" behind Well's "fast-thinking answer" is: During 9 day-and-night, the snail will climb 27 units. To climb 3 missing units, it would need only a half of the 10th day.

Slow-thinking answer is quite different. During eight days and eight nights, the snail would climb up 24 units and during the ninth day, after climbing missing 6 units, the snail would reach the edge of the well. 


\section{Popularity of the climbing-snail problem}

Before presenting evidence of its popularity, it is important to know that the climbing-snail problem has attracted the attention of well know mathematicians, like Peano and Arnold:

"A snail is climbing along a 5-meter high wall. Every day climbs three meters and every night descends 2 meters. After how many days does the snail reach the top of the wall?" (Peano, 1925, pp. 3-4)

"During the daytime a snail climbs $3 \mathrm{~cm}$ up a post, and during the night, falling asleep, accidentally goes down by $2 \mathrm{~cm}$. The post is $10 \mathrm{~m}$ high, and a delicious (for the snail) sweet is on its top. In how many days will the snail get the sweet?" (Arnold, 2004, Problem 10, p. 4)

The problem is very popular on puzzle websites:

"A snail decides to reach the roof of a house. The wall is 10 meters high. The snail climbs during the day three meters, but at night he slips and falls two meters. How long it takes for the snail to reach the roof?" (Toppuzzle, n. d.)

"A snail is at the bottom of a 20 meters deep pit. Every day the snail climbs 5 meters upwards, but at night, it slides 4 meters back downwards. How many days does it take before the snail reaches the top of the pit?"(Queryhome, n. d.)

Some websites provide useful information that shows how prone are even adults in getting an incorrect answer to the problem. In Japan, on a "brain training" site, the quiz problem 8 "Snail" goes like this:

"There is a snail at the bottom of a well whose depth is $7 \mathrm{~m}$. This snail is climbing $3 \mathrm{~m}$ of the well wall in one hour and it immediately slides down $2 \mathrm{~m}$ after the climb. Well, if this snail gets out of the well, how many hours would it take?" (ZeroBrain, n. d.)

The problem animated 6.820 persons to give their answers. Among them, 3.883 answers (57 \%) were correct and 2.937 answers (43\%) were incorrect. So, even for adult persons in a highly industrialized country like Japan, the likeness of wrong answers is still bigger than $40 \%$. In other words, on average, more than 4 in 10 persons would fall in the mental trap the puzzle creates in people's mind.

In mathematics education, the climbing-snail problem has been present, at least, since 1850 :

"A snail in getting up a pole 20 feet high, was observed to climb up 8 feet every day, but to descend 4 feet every night: in what time did he reach the top of the pole?" (Davies, 1850, Promiscouos question 23, p. 363).

Over many years, it was used, in formulations with different climbing animals (monkey, frog,snail,...) by the authors of five articles published in the journals of National Council of Teachers of Mathematics (Earl, 1966; Bradfield, 1970; Jensen \& O’Neil, 1982; van de Walle, O’Daffer, \& Charles, 1988; Kelly, 1999).

The fact that the climbing-snail problem activates "fast thinking", leading to a wrong answer, makes it a very good item for the books on mathematical problem solving written for teachers (Posamentier \& Krulik, 2008; Posamentier \& Krulik, 2009; Sonnabend, 2010).

In Mexico, the problem appears in two mathematics textbooks for secondary school, with following formulations:

"A snail wants to get to the edge of a wall having 9-meter height. Every day climbs up $4 \mathrm{~m}$ and during night slides down $2.5 \mathrm{~m}$. In how many days will the snail get to the edge?" (Olea Díaz et al., 2009)

"A snail tries to get out of a small well whose depth is $3 / 4 \mathrm{~m}$. During day it climbs up $1 / 6 \mathrm{~m}$, but during night gets back $1 / 12 \mathrm{~m}$. How many days will it need to get out?" (Escareño \& López, 2008)

The popularity of this problem goes well beyond mathematics education. For example, in Italy, its different formulations can be found in computer books (Camagni, 2010) and books on visual intuition (Antonietti et al., 2007). 
In exam books for future engineers (Bertocchi, 2012) and teachers (Bianchini \& Borgonovo, 2012), the problem is posed in multiple-choice format with five possible answers. One example is:

"A snail has to overcome a 12-meter high wall. During the day it climbs up 4 meters, but at night, when sleeping, it slips downward 3 meters. How many days will take the snail on top of the wall?

(A) 5; (B) 9; (C) 12; (D) 10; (E) 7." (Bertochi, 2012, Problem 1397, p. 217)

Although the correct answer is choice (B), for fast thinkers more appealing would be the choice (C).

The influence of the position of the correct answer in multi-choice problems on its difficulty for problem solvers is a still debated issue in the theory of design of multi-choice items in educational testing. Attali and Bar-Hillel (2003) consider that questions with extreme positions (the first and the last) of the correct answer are more discriminating. Hohensinn and Baghaei (2017) are even more specific. They state that last position of the correct answer makes a multi-choice item more difficult. In our pilot research, we explored the influence of the position of the correct answer on Mexican students' performances for the climbing-snail problem.

\section{Previous research studies}

Although the climbing-snail problem is very popular, there are only a few research studies focused on fine details of students' performances.

In a qualitative exploration study, D'Amore (1995) has collected and analyzed a very impressive collection of spontaneously-generated drawings related to solving a version of climbing-snail problem. These drawings were provided by Italian primary school students (between 5 and 11 years) and secondary school students (between 11 and 16 years).

In a pilot intervention study (Diezman, 1997), carried out with 12 students (average age of 10.25 years), two versions of problem were used, differing in surface features (climbing animal and situation). In the pre-test formulation a koala was climbing a tree and in the post-test formulation a frog was climbing a wall. It was shown that an instructional program, consisting in general hints and explicit prompts for those students unable to spontaneously get a diagram, could improve students' generation of diagrams, useful for problem solving.

A recent study (Reuter et al., 2015), involving 199 4th-graders, used climbing-snail problem, too. Nevertheless, this study got less optimistic results. It turned out that providing drawings or tables did not facilitate problem solving in general. If a representation was provided, a drawing was more helpful than a table. However, the drawing effect was depending on the problem type and the level of pre-structuring.

\section{Student sample, research questions and methodology of this small-scale pilot study}

Pre-university schooling system in Mexico has three stages and lasts 12 years. Primary school (escuela primaria) lasts 6 years (grades 1 through 6 of primary school). Students start primary school when they are 6-year old. Secondary school (escuela secundaria) lasts 3 years (grades 1 through 3 of secondary school). Primary and secondary schools belong to so-called "basic education" (educación básica). The last stage is preparatory school (escuela preparatoria) lasts also 3 years (grades 1 through 3 of preparatory school).

This small-scale pilot study was carried out with 4 different groups of secondary and preparatory school students.

Our research questions were:

1) Do students' performances in solving climbing-snail problem depend on students' ages?

2) Do students' performances in solving climbing-snail problem depend on the position of the correct answer in multiple-choice format? 
Although recent research results advocate use of computer-based assessment (Threfall et al. 2007; Adesina et all., 2014), due to lack of classroom technology, this pilot study was of a structured, multitask paper-and-pencil type. The student worksheet had the following elements:

\section{Formulation of the climbing-snail problem}

"Without revealing his reasons, a snail decided to climb a pole whose height is 10 meters. During day he climbs 3 meter, but during night he slides 2 meters. How many days and how many nights does the snail need to climb to the top of the pole?"

2. Four offered answers in multiple-choice format

In the Version A, the correct answer " 8 days and 7 nights" was the first option.

(a) 8 days and 7 nights.(b) 9 days and 8 nights.

(c) 10 days and 9 nights.(d) 10 days and 10 nights.

In the version $\mathrm{B}$, the correct answer " 8 days and 7 nights" is the last option.

(a) 10 days and 10 nights.(b) 10 days and 9 nights.

(c) 9 days and 8 nights.(d) 8 days and 7 nights.

3. Students were asked to organize their problem solving, completing the tasks presented in the Table 1.

Table 1. Structured students' tasks

Draw the situation presented in this problem.

Describe by your own words how you understand the problem.

Describe and justify the operations you used to get your initial solution.

Describe and justify the operation you used to get eventually a final solution different than the initial one.

Argue why you believe your solution (initial or final) is correct one.

In the case you could not get any solution, describe what was the reason.

\section{The results when the correct answer was the first choice}

In this part of the research, the sample consisted of 30 secondary-school students (73\% male, $27 \%$ female; average age 12.10 year) and 38 preparatory-school students (37 \% male, $63 \%$ female, average age 15.08 years).

The results are given in the Table 2 .

As it can be seen from the Table 2, older students have much more correct answers (8 days and 7 nights) and less "fast answers" (10 days and 10 nights).

\section{The results when the correct answer was the last choice}

In this part of the research, the sample was made of 40 secondary-school students ( $45 \%$ male, $55 \%$ female; average age 12.15 year)and 41 preparatory-school students (41\% male, $59 \%$ female, average age 15.50 years).

The results are given in the Table 3.

In this case, older students again have more correct answers (8 days and 7 nights), although the difference is much smaller than before. In addition, now they have more "fast-thinking answers" (10 days and 10 nights).

In general, regarding the performance leading to correct answers with acceptable procedure, three-year older students have a much better score (in total: 15 answers vs. 1 answer).Nevertheless, the propensity toward "fast-thinking answer" doesn't depend too much on students' ages (in total: 28 answer vs. 26 answer).

The influence of the position of correct answer in four-choice format (the first position vs. the last position) is a little bit enigmatic. Namely, it only affected the performance of the older students, reducing the percentage of correct-answer score more than four times, from $32 \%$ (the correct answer is the first choice) to $7 \%$ (the correct answer is the last choice). 
Table 2. The answer selected in the Version A (The correct answer, 8 days and 7 nights, is the first choice). Total number of secondary-school students (SSS) was $N_{\text {SSS }}=30$. Total number of preparatory-school students (PSS) was $N_{P S S}=30$.

\begin{tabular}{|l|c|c|c|c|}
\hline \multicolumn{1}{|c|}{ Selected answer } & $\begin{array}{c}\text { Number of choices } \\
\text { for SSS }\end{array}$ & $\begin{array}{c}\text { Percentage of } \\
\text { choices for SSS } \\
(\%)\end{array}$ & $\begin{array}{c}\text { Number of choices } \\
\text { for PSS }\end{array}$ & $\begin{array}{c}\text { Percentage of } \\
\text { choices for PSS }\end{array}$ \\
\hline $\begin{array}{l}8 \text { days and 7 nights } \\
\text { (acceptable procedure) }\end{array}$ & 0 & 0 & 12 & 31,58 \\
\hline $\begin{array}{l}8 \text { days and 7 nights } \\
\text { (inacceptable procedure) }\end{array}$ & 2 & 6,67 & 11 & 28,95 \\
\hline 9 days and 8 nights & 2 & 6,67 & 0 & 0 \\
\hline 10 days and 9 nights & 5 & 16,67 & 2 & 31,58 \\
\hline 10 days and 10 nights & 15 & 50 & 1 & 2,63 \\
\hline No answer selected & 2 & 6,67 & 0 & 0 \\
\hline $\begin{array}{l}\text { Two selected answers } \\
\text { or hard-to-understand } \\
\text { answers }\end{array}$ & 4 & 13,33 & & \\
\hline
\end{tabular}

Table 3. The answer selected in the Version B (The correct answer, 8 days and 7 nights, is the last choice). Total number of secondary-school students (SSS) was $N_{\text {SSS }}=40$. Total number of preparatory-school students (PSS) was $N_{\text {PSS }}=41$.

\begin{tabular}{|l|c|c|c|c|}
\hline \multicolumn{1}{|c|}{ Selected answer } & $\begin{array}{c}\text { Number of } \\
\text { choices for SSS }\end{array}$ & $\begin{array}{c}\text { Percentage of } \\
\text { choices for SSS } \\
(\%)\end{array}$ & $\begin{array}{c}\text { Number of } \\
\text { choices for PSS }\end{array}$ & $\begin{array}{c}\text { Percentage of } \\
\text { choices for PSS }\end{array}$ \\
\hline $\begin{array}{l}\text { 8 days and 7 nights } \\
\text { (acceptable procedure) }\end{array}$ & 1 & 2,50 & 3 & 7,32 \\
\hline $\begin{array}{l}8 \text { days and 7 nights } \\
\text { (inacceptable procedure) }\end{array}$ & 9 & 22,5 & 6 & 14,63 \\
\hline 9 days and 8 nights & 4 & 10,00 & 6 & 14,63 \\
\hline 10 days and 9 nights & 14 & 35,00 & 9 & 21,95 \\
\hline 10 days and 10 nights & 11 & 27,50 & 16 & 39,02 \\
\hline No answer selected & 1 & 2,50 & 1 & 2,44 \\
\hline
\end{tabular}

To understand better existence, level and meaning of this influence, further studies are needed, with a bigger sample and a better methodology approach. Namely, in this study students' working sheets with different positions of the correct answer in multiple-choice format were given to two different student groups. To reduce a possible influence of various potential differences between student groups, two different working sheets (the correct answer as the first and as the last choice) should be given to randomly chosen students' halves in every involved group.

\section{Some particular students' performances in solving the climbing-snail problem}

In this section we present and comment some particular students' performances in solving the climbing-snail problem. We did not find any student 
who had strategic approach to problem by offering a following consideration: The snail must come to the top by climbing up during the day, not by sliding down during the night. Coming down to the top would imply a "flying snail".

The lack of this fundamental consideration will be seen later in many students' arithmetic procedures where flying-snail error is present implicitly or explicitly.

1. Acceptable procedures to justify selection of the correct answer "8 days and 7 nights"

We first present a few acceptable procedures of students' justifications. These procedures took different representational forms.

\subsection{Verbal justifications}

Very few students were able to provide a verbal justification for the correct answer. One example goes as follows:

"In the morning it climbs up 3 meters, but, as in the night it slides down 2 , in a whole day it climbs only one meter. In the night 7 it has travelled up 7 meters, then in the day 8 it reaches 10 meters.

This result is probably due to the lack of verbal argumentation practice in traditional mathematics classrooms

1.2. Schematic justifications on a horizontal "numberless" number line

Some students tried to solve the problem by using different versions of vertical and horizontal number line. It was interesting to note that nobody of them indicated the values corresponding to the points on the number line. In other words, they created what might be called "numberless" line. The other important finding is the only students who used horizontal number line produced acceptable schematic justifications. Two of them are given in Figure 1 and Figure 2.

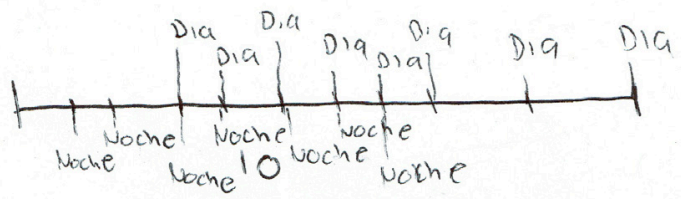

Figure 1. A horizontal number line with words "Día" (Day) and "Noche" (Night).

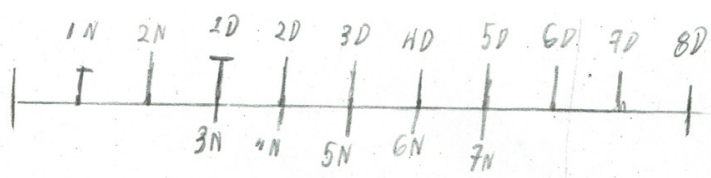

Figure 2. A horizontal number line with elegant symbols for numbered days $(1 D, 2 D, \ldots)$ and nights $(1 N, 2 N, \ldots)$.

In the second case (Figure 2), the student had a clear insight that the snail's position at the end of the third night is the same as the position of the snail at the end of the first day, at the end of fourth night the same as the position at the end of the second day and so on!

Nevertheless, the former case (Figure 1) has a subtle advantage: signs for all nights are under the number line, while signs for all days are above the number line. In a productive discussion, these two students might come to a more coherent representation: $1 \mathrm{~N}, 2 \mathrm{~N}, \ldots, 7 \mathrm{~N}$ are under the number line.

Very few students could present a schematic justification in which it was clear how different positions of the snail were connected. The best one of them is shown in Figure 3.

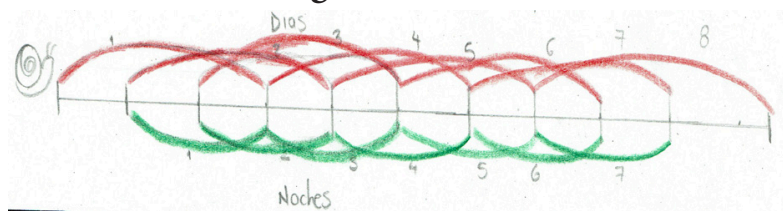

Figure 3. A schematic justification for the correct answer $($ Días $=$ Days $;$ Noches $=$ Nights $)$

Answering the question "Why do you believe your solution is correct?", the author of this scheme said: 
Because I did it step-by-step and marked the night and the day by a different color.

\section{bologies}

1.3. Tabular justification and interesting sym-

Only one student was able to generate an acceptable tabular justification:

$\begin{array}{lcccc}\text { Day } & \text { Night } & \text { Day } & \text { Night } & 8 \text { days } \\ 3 & 1 & 7 & 5 & 7 \text { nights } \\ 4 & 2 & 8 & 6 & \\ 5 & 3 & 9 & 7 & \\ 6 & 4 & 10 & & \end{array}$

Obviously, this student writes the positions of the snail at the end of every day and night. The table shows that the snail gets to the position " 10 " at the end the eight day. No unit for the heights was used.

Students were more successful in proposing interesting symbologies for getting the answer " 8 days and 7 nights". We provide two of them:

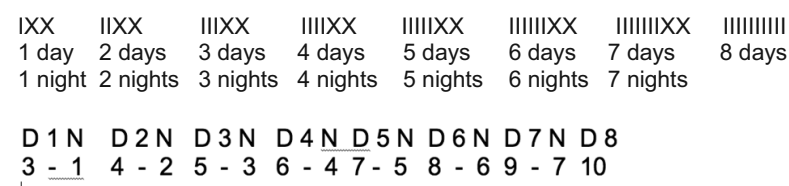

2. Unacceptable procedures to justify selection of the right answer " 8 days and 7 nights"

There are two unacceptable procedures to justify selection of the right answer " 8 days and 7 nights".

2.1 Checking if the numbers of days and nights give the height of the pole

Many students just write down three arithmetic operations:

$$
\begin{gathered}
8 \times 3=24 \\
7 \times 2=14 \\
24-14=10
\end{gathered}
$$

Some students have their own notation (Figure 4):

$$
\begin{array}{r}
8 \\
+3 \\
\hline 24
\end{array}-\frac{7}{14}=10 \mathrm{~m}
$$

Figure 4.

An example of student's own notation.
Some, but not too many, students' describe verbally what they do. Here come four examples:

"If we multiply $3 \times 8=24$ is what it climbs in 8 days. Also, if we multiply 7 × $2=14$ and subtract, there are 10 meters."

"If it took 8 days, it is supposed that I multiplied the 8 days by the meters it climbs and the 7 nights I multiplied by what it slid."

"If every day it climbs 3 meters and in every night slides 2 meters, in 8 days and 7 nights it climbed $24 \mathrm{~m}$ and has slid 14, we are left with the result 24 $\mathrm{m}-14 \mathrm{~m}=10 \mathrm{~m}$."

"Every day has value of 3 and every night has a value of 2. So, only has to multiply and after subtract."

2.2. Arbitrary constructed argument for the correct answer

Although checking tactic is not an acceptable procedure for getting the correct answer, it is conceptually clear. More worrying examples of "argument" for the correct answer are those in which the numbers of days and nights (8 and 7) are arbitrary constructed from the data given in the problem (10 $\mathrm{m}, 3 \mathrm{~m} /$ day, $2 \mathrm{~m} / \mathrm{night}$ ), without any conceptual base. Two examples of this "argument" are given in the Figure 5.
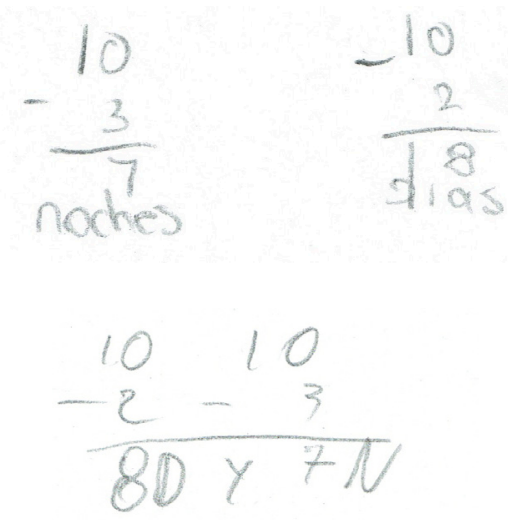

Figure 5. The correct numbers of days and nights are arbitrary constructed (noches $=$ nights; días $=$ days $)$. 
These students do not note that the result of subtraction of two numbers expressed in meters can't be a number expressing the quantity of days or nights. In addition, these examples reveal students' wrong belief that in mathematics problems the answer should be obtain by carrying out blindly basic operations with the given data.

3. Common students' procedures that lead to an incorrect, "fast-thinking" answer

Students' performances revealed three basic procedures that guided them to an incorrect, "fastthinking" answer. The first is based on factual insight "1 meter per day-and-night" and the other is step-by-step calculation composed of summing and subtracting. In the later students frequently make, implicitly or explicitly, "flying-snail error" and break arithmetic syntax. Only one student has chosen tabular approach. Strictly speaking, the fourth procedure is not an answer-generating one, but rather an already-mentioned checking tactic that is carried out by inserting problem data in offered "fast-thinking" answer. answer

3.1. Verbal argument for the "fast-thinking"

Already-commented verbal reasoning was found in some students:

"Because if it climbs $1 \mathrm{~m}$ during one day and one night, during 10 days and 10 nights it will be 10 m."

"Due to logic, if it climbs in one day 3 meters and in the night if slides 2, it is obvious that it only climbs 1 meter in one day and one night. If there are 10 meters, there are 10 days and 10 nights."

"In one day and one night it climbs $1 \mathrm{~m}$. If the pole has a height of $10 \mathrm{~m}$, then it needs 10 days and 10 nights."
"Because the snail climbs $1 \mathrm{~m}$ per a day and a night and to get to $10 \mathrm{~m}$ there should be 10 days and 10 nights."

3.2. Arithmetic procedures with explicit or implicit "flying-snail" error

Big majority of students used arithmetic approach with all ten step-by-step calculations with two notable phenomena: incorrect arithmetic syntax and/or overseeing implicit or explicit flyingsnail error.

Here come two examples of incorrect arithmetic syntax with explicit flying-snail error:

\section{First example}

$$
\begin{array}{ll}
3-2=1 & 7+3=10-2=8 \\
1+3=4-2=2 & 8+3=\mathbf{1 1}-2=9 \\
2+3=5-2=3 & 9+3=\mathbf{1 2}-2=10 \\
3+3=6-2=4 & \\
4+3=7-2=5 & \\
5+3=8-2=6 & \\
6+3=9-2=7 &
\end{array}
$$

\section{Second example}

$3-2=1+3=4-2=2+3=5-2=3+3=$ $6-2=4+3=7-2=5$

$5+3=8-2=6+3=9-2=7+3=10-2=$ $8+3=11-2=9+3=12-2=10$

Explicit flying-snail error was also found when students perform arithmetic operations mentally. This case can be seen in the Figure 6.
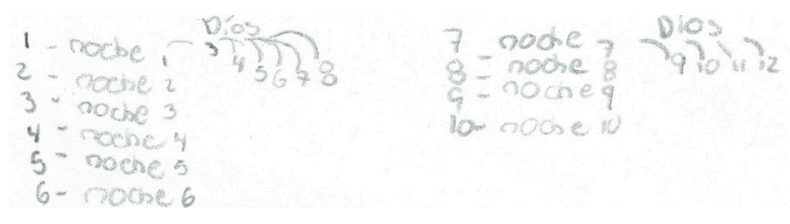

Figure 6. Example of explicit flying-snail error with hidden arithmetic operations (noche $=$ night, Días $=$ days $)$ 
Students who respected arithmetic syntax made mainly implicit flying-snail error (Figure 7).

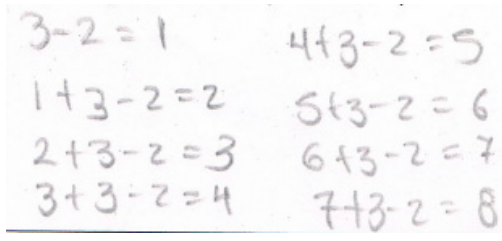

Figure 7. An example student's work with correct arithmetic syntax and implicit flying-snail error

$(8+3,9+3)$.

An original way to "violate" arithmetic rules was a work with "exponential" notation (Figure 8).

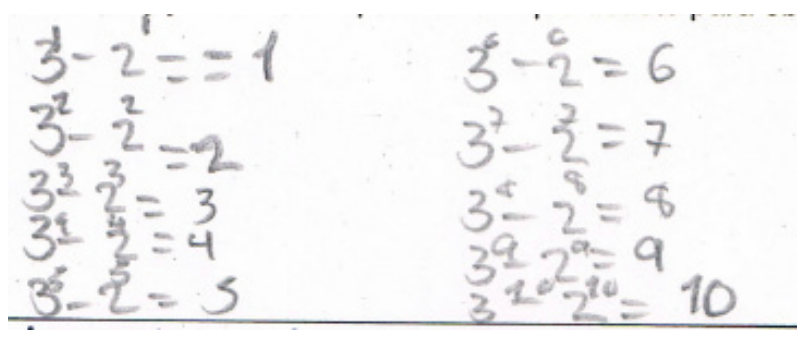

Figure 8. An original way to "violate" arithmetic rules.

It seems that in this "exponential" notation the "exponents" play a twofold role: an accounting tool for number of the passed days and nights and a shorthand replacement of multiplication. With that interpretation, what student had on mind might have been the following (correct!) arithmetic operations and results:

$$
\begin{aligned}
& (3 \times 1)-(2 \times 1)=1 \\
& (3 \times 2)-(2 \times 2)=2 \\
& (3 \times 3)-(2 \times 3)=3 \\
& (3 \times 4)-(2 \times 4)=4 \ldots
\end{aligned}
$$

Of course, a follow-up interview with the student in question would be the best way to learn student's thoughts and reasons for the above notation.

3.3. Getting "fast-thinking answer" through a table representation
Only one student used a table to get incorrect answer "10 days and 10 nights". His or her work is shown in Figure 9a and Figure 9b.

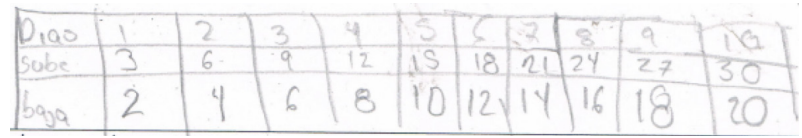

Figure 9a.A tabular approach to get incorrect answer. $($ Dias $=$ Days, sube $=$ goes $u$, baja $=$ goes down)

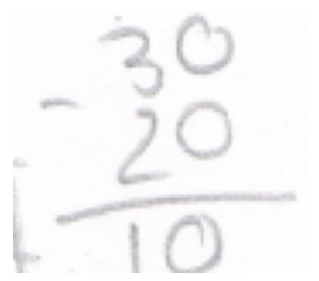

Figure 9b. Closing subtract operation

It is natural to suppose that subtract operation was used to show that calculated sums of "climbing ups" (in 10 days) and "sliding downs" (in 10 nights) give a correct height of the pole.

3.4. Justifying selected incorrect answer by two multiplications and a subtraction

As in the case of correct answer " 8 days and 7 nights" (see above), some student "justified" their incorrect answer "10 days and 10 nights" by two multiplications and a subtraction:

$$
\begin{aligned}
& 10 \times 3=30 \\
& 10 \times 2=20 \\
& 30-20=10
\end{aligned}
$$

Very few students give verbal description of operations' meaning (although carelessly worded):

"Goes up 3 meters during 10 days $=30 \mathrm{~m}$

Goes down 2 meters during 10 nights $=20 \mathrm{~m}$ "

"If in all days it climbs up $3 \mathrm{~m}$ in 10 it will climb up 30, but as in the nights it goes down $2 \mathrm{~m}$ in 10 days it will be 20 , it is subtracted from 30 and one gets 10." 
So, multiple-choice format of problem induces in some student an undesirable behavior. Instead of trying to get their answers, they just check if an offered answer fits the condition of the problem.

4. Relationship between the nature of visualization and poor performance in mathematics problem solving

According to Hegarty and Kozhenikov (1999), students create two types of visual-spatial representations of problem situations. Pictorial representations encode the visual appearance of the objects involved in the problem, while schematic representations capture their abstract spatial configuration and mathematical structure of the problem.

Hegarty and Kozhenikov (1999) found that the use of schematic spatial representations was associated with success in mathematical problem solving, whereas use of pictorial representations was negatively correlated with success. It was found in this study that many of students' poor performances show a notable correlation with very pictoric problem representation. One example is given in the Figure 10.

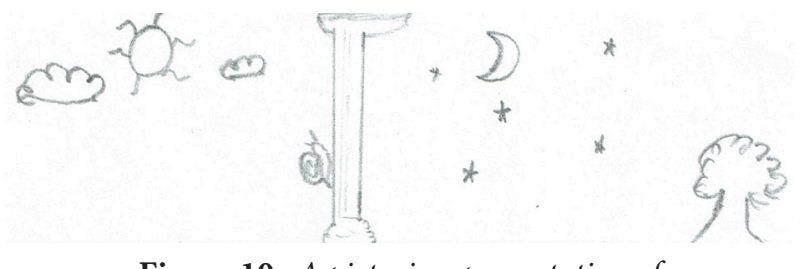

Figure 10. A pictoric representation of climbing-snail problem.

Although the student has chosen the right answer, his or her argument was without any mathematical idea.

\section{Conclusions}

In spite of being a small-scale pilot study, we consider that its results have some valuable implications for teaching. Therefore we suggest the following:
1. Teachers should avoid, whenever it is possible, to give students multiple-choice problems.

In this way, students are obliged to get a solution by using their own means, instead of checking approach. In the case when multiple-choice problem must be given (due to any reason), students should be asked to provide the reasons for selecting one particular answer.

2. Teachers should ask students constantly to provide verbal arguments for what they do in problem solving and why they do it.

The best approach is to practice with them four steps of Polya: (1) understanding the problem; (2) planning a solution path; (3) carrying out the plan and(4) evaluating the result. These steps should be required in all problem-solving activities, especially in the exams. Some (if not many) students avoid learning those skills and procedures that won't be part of their exams.

3. Teachers should always stimulate students to get as-many-as-possible different representations and procedures for getting a solution for all problems students deal with (verbal, tabular, schematic,...).

This practice, when implemented constantly, stimulates students' creativity and fights a common students' belief that all mathematical problems have only one solution, known by their teacher or by best students.

4. Teacher should show students explicitly the differences between pictoric and schematic representations of problem situations and should give them multiple opportunities to move from a pictoric to a schematic one, first with and later without teacher's help.

That teaching task might be hard one because many mathematics textbooks frequently insert mathematical models into drawings (or even photos!) that represent problem situation.

5. Teacher should show to students the importance of taking into account the units of physical quantities when problems are physics-related. 
This important aspect is also spoiled by solved examples in mathematics textbooks. Namely, it is common that the units of calculated quantities (length, area, volume, speed, traveled distance,...) appear only in the final results. In other words, the units should be carefully included in all calculation steps. Students, who understood and practiced "unit approach" well, would hardly "calculate" the numbers of days resting a night speed from the height of the pole!

\section{References}

- Adesina, A., Stone, R., Batmaz, F., \& Jones, I. (2014). Touch Arithmetic: A process-based Computer-Aided Assessment approach for capture of problem solving steps in the context of elementary mathematics. Computers \& Education, 78, 333-343.

- Antonietti, A., Angelini, Ch., \& Cerana, P. (2007). L'intuizione visiva. Utilizzare le immagini per analizzare e risolvere i problemi. Milano: FrancoAngeli/Trend, "La lumaca tenace", p. 39

- Arnold, V. I. (2004). Problems for children from 5 to 15. http://jnsilva.ludicum.org/HMR13 14/Arnold en.pdf(Accessed on January 15, 2017)

- Attali, Y., \& Bar-Hillel, M. (2003). Guess Where: The Position of Correct Answers in Multiple-Choice Test Items as a Psychometric Variable. Journal of Educational Measurement, 40(2), 109-128.

- Averbach, B., \& Chein, O. (2012). Problem solving through recreational mathematics. New York: Dover.

- Bertocchi, S. (2012). 3500 quiz ingegneria. I quesiti per le prove di ammissione. Milano: Alpha Test, Question 1397, p. 217

- Bianchini, M., \& Borgonovo, P. (editors). (2012). La prova a test del concorso insegnanti. Manuale di preparazione. Con CD-ROM. Milano: Alpha Test, Question 10, p. 15

- Bradfield, D. L. (1970). Sparking interest in the mathematics classroom. The Arithmetic Teacher, 17(3), 239242.

- Camagni, P. (2010). Algoritmi e basi della programmazione. Milano: Editore Ulrico Hoepli. "La lumaca sul muro", p. 98.

- D’Amore, B. (1995). Uso spontaneo del disegno nella risoluzione di problemi di matematica.La matematica e la sua didattica. 3, 328-370.

- Danesi, M. (2002). The Puzzle Instinct: The meaning of puzzles in human life. Bloomington: Indiana University Press.

- Davies, C. (1850). The university arithmetic: embracing the science of numbers, and their numerous applications. New York: A. S. Barnes \& Company

- Deschauer, S. (2013). Das zweite Rechenbuch von Adam Ries: eine moderne Textfassung mit Kommentar und metrologischem Anhang und einer Einführung in Leben und Werk des Rechenmeisters. Berlin: Springer-Verlag.

- Diezmann, C. M. (1997).The effect of instruction on students' generation of diagrams.In Biddulph, F. \& Carr, K. (editors) (1997).Proceedings 20th Annual Conference of Mathematics Education Research Group of Australasia: People in mathematics education. Rotorua: New Zealand, pp. 140 - 146.

- Dohmen, T., Falk, A., Huffman, D., \& Sunde, U. (2010). Are risk aversion and impatience related to cognitive ability?. The American Economic Review, 100(3), 1238-1260.

- Dudaitè, J. (2013). Item Format Influence on the Results of the Item. Societal Studies, 5(3), 515 - 524. 
- Earl, W. (1966). An iconoclastic elementary school mathematics program. The Arithmetic Teacher, 13(6), 489-491

- Escareño, F. y López O. L. (2008). Matemáticas 1. México D.F.: Editorial Trillas, p. 73.

- Frederick, S. (2005). Cognitive reflection and decision making. Journal of Economic Perspectives, 19(4), 2542.

- Gardner, M. (1998). A Quarter-Century of Recreational Mathematics. Scientific American - American Edition, 279, 68-75.

- Hegarty, M., \& Kozhevnikov, M. (1999).Types of visual-spatial representations and mathematical problem solving.Journal of educational psychology, 91(4), 684 - 689.

- Hohensinn, C., \& Baghaei, P. (2017). Does the Position of Response Options in Multiple-Choice Tests Matter?. Psicológica, 38, 93-109.

- Jensen, R., \& O’Neil, D. R. (1982). Classical problems for all ages. The Arithmetic Teacher, 29(5), 8-12.

- Kahneman, D. (2011). Thinking, fast and slow. New York: Farrar, Strauss and Giroux.

- Kelly, J. A. (1999). Improving problem solving through drawings. Teaching Children Mathematics, 6(1), 4851.

- Kosanić, G. (n. d.). Од давнина до данашњих дана - стари математички задаци https:/gocateacher. wordpress.com/page/10/ (Accessed on September 25, 2016).

- Massa Esteve, M. R. (2014). Historical activities in the mathematics classroom: Tartaglia's Nova Scientia (1537). Teaching innovations, 27(3), 114-126. doi:10.5937/Inovacije1403114E

- Matka (n. d.) http://www.matka.gradnet.hr/zabavna matematika.htm)(Accessed on January 15, 2017)

- Meyer, E. F., Falkner, N., Sooriamurthi, R. y Michalewicz, Z. (2014). Guide to Teaching Puzzle-based Learning. London: Springer.

- Michalewicz, Z. y Michalewicz, M. (2008) Puzzle-based learning: an introduction to critical thinking, mathematics, and problem solving. Melbourne: Hybrid Publishers.

- Olea Díaz, A., Basurto Hidalgo E. \& Rivera Paredes, M. A. (2009). Contexto Matemático 1. Primera edición, Tlalnepantla de Baz, Estado de México: Norma ediciones, p. 66.

- Peano, G. (1925). Giochi di aritmética e problemi interessanti. Torino: Paravia.

- Posamentier, A. S. \& Krulik, S. (2008). Problem-Solving Strategies for Efficient and Elegant Solutions. Grades 6-12. A Resource of the Mathematics Teacher. Second Edition. Thousand Oaks, CA: Corwin Press, Problem 7.19.

- Posamentier, A. S. y Krulik, S. (2009). Problem solving in mathematics. Grades 3 - 6: Powerful strategies to deepen understanding. Thousand Oaks, CA: Corwin, Problem 9.2.

- Poundstone, W. (2003). How Would You Move Mount Fuji? Microsoft's Cult of the Puzzle. How the World's Smartest Companies Select the Most Creative Thinkers. New York: Little, Brown and Company.

- Poundstone, W. (2012). Are you smart enough to work at Google? Fiendish Puzzles and Impossible Interview Questions from the World's Top Companies. Oxford: Oneworld Publications

- Queryhome (n. d.). http://puzzle.queryhome.com/516/how-many-days-does-take-before-the-snail-reaches-the-top-the-pit(Accessed on January 15, 2017) 
- Reuter, T., Schnotz, W., \& Rasch, R. (2015). Drawings and tables as cognitive tools for solving non-routine word problems in primary school. American Journal of Educational Research, 3(11), 1187-1197.

- Schaaf, W. L. (1955). A Bibliography of Recreational Mathematics. Volumes I - IV. Reston, VA: National Council of Teachers of Mathematics.

- Sigler L.E. (2002). Fibonacci’s Liber Abaci. Leonardo Pisano's Book of Calculation. First soft edition. New York: Springer.

- Singmaster, D. (2004). Sources in recreational mathematics. An annotated bibliography. Eight preliminary edition (2004).10.H. SNAIL CLIMBING OUT OF WELL. http://puzzlemuseum.com/singma/singma6/ SOURCES/singma-sources-edn8-2004-03-19.htm\# Toc69534272 (Accessed on September 25, 2016)

- Sliško, J. (2016). Zabavni zadatak u vezi sa kretanjem puža - dvije epizode malo poznate ali poučne povijesti matematike (A funny problem related to the motion of a snail - two episodes of little known but instructive history of mathematics). Matematika u školi, 83, 132- 135.

- Sonnabend, T. (2010). Mathematics for Teachers: An Interactive Approach for Grades K-8. Fourth edition. Belmont, CA: BROOKS/COLE CENGAGE Learning, Problems 12 and 13, p. 60

- Threlfall, J., Pool, P., Homer, M., \& Swinnerton, B. (2007). Implicit aspects of paper and pencil mathematics assessment that come to light through the use of the computer. Educational Studies in Mathematics, 66(3), 335-348.

- Toppuzzle (n. d.).http://en.toppuzzle.eu/puzzles-easy.html(Accessed on January 15, 2017)

- van de Walle, J., O’Daffer, P. G., \& Charles, R. I. (1988). Problem solving: Tips for teachers. The Arithmetic Teacher, 35(5), 26-27.

- Wells, D (2012). Games and mathematics. Subtle connections. New York: Cambridge University Press.

- Zero-Brain (n. d.) http://zero-brain.com/pc/quiz/8/index.php(Accessed on January 15, 2017) 
Каролина Сенобио Касӣиљо,

Јосий А. Слишко,

Лияија Ернандес Ребољар,

Аgријан Корона Крус

Факултет за физику и математику (за математичке и физичке науке)

Аутономни универзитет, Пуебла, Мексико

\section{НЕКОЛИКО ОСВРТА НА ЗАДАТАК О ПУЖУ КОЈИ СЕ ПЕЊЕ: ФИБОНАЧИЈЕВА ГРЕШКА, ПОПУЛАРНОСТ ПРОБЛЕМСКОГ ЗАДАТКА И РЕШЕЊА МЕКСИЧКИХ СТУДЕНАТА}

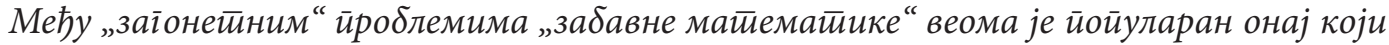

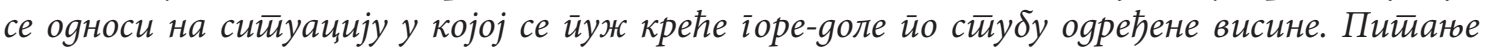

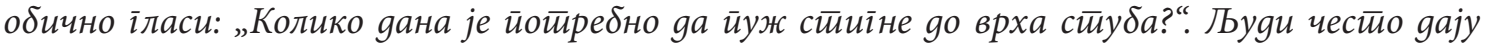

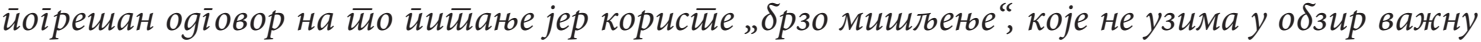

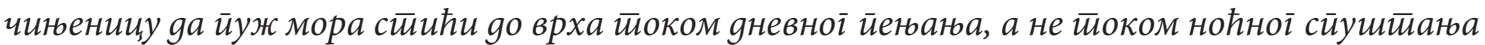

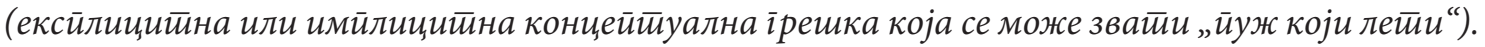

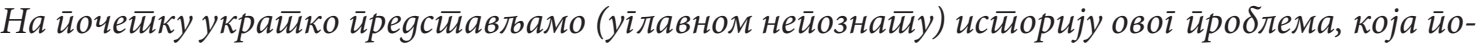
казује gа су йоірешно решене gавали и неки йознайи среgюовековни матиематиччари као итио су били Фибоначи, Каландри и Рис.

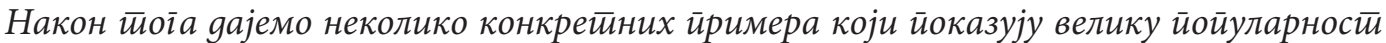

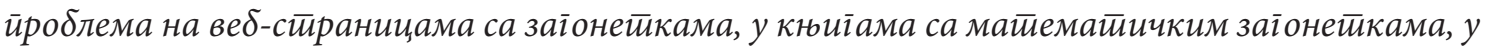

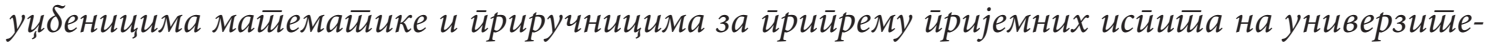

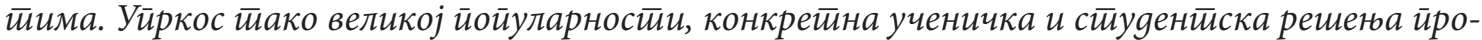

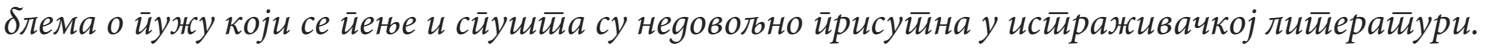

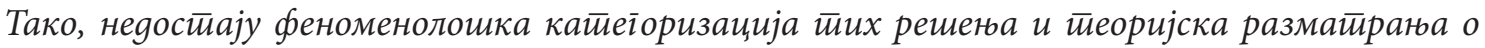
ғиховим моїућим узроцима.

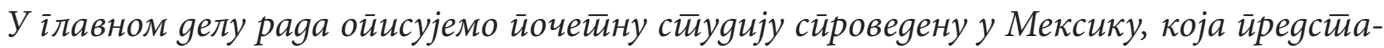

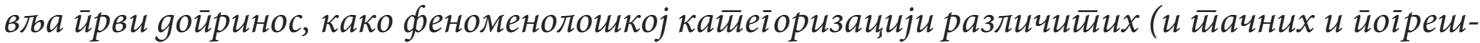

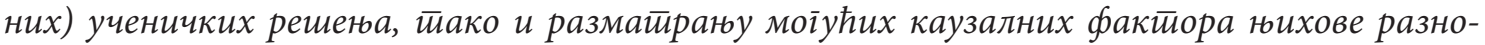

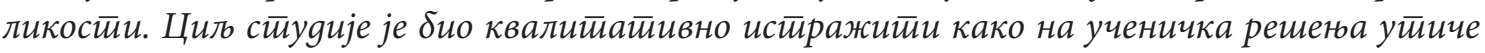

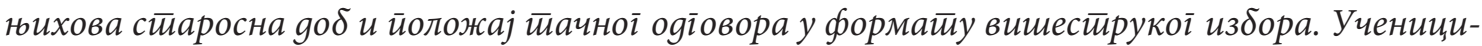

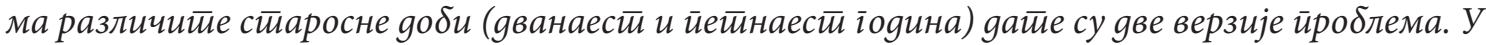

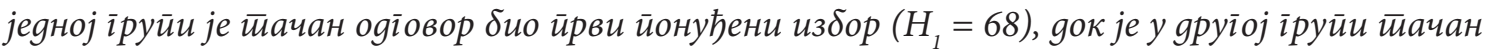
оgі̄овор био йослеgюи йонуђени избор $\left(\mathrm{H}_{2}=81\right)$.

Добијени резулитайи ӣоказују gа на ученичка решеюа уйичу како юихова ситаросна

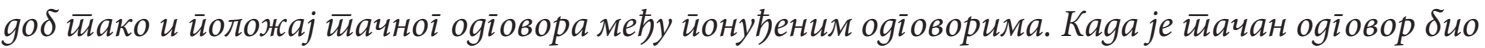

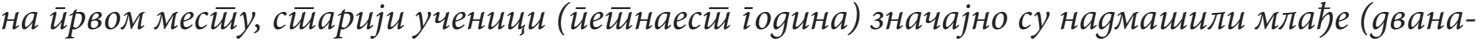

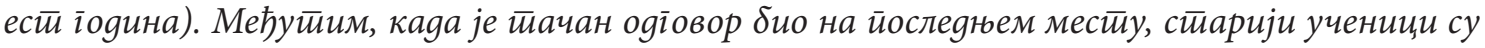
били йек незнайно боли.

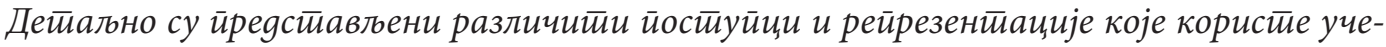

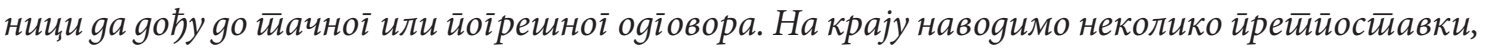




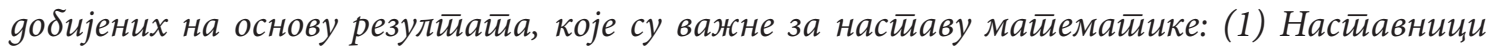

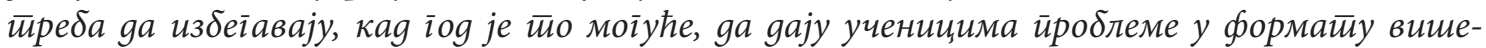

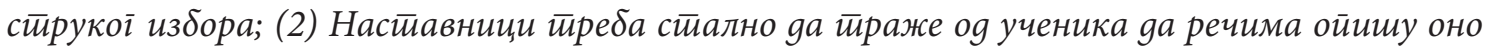

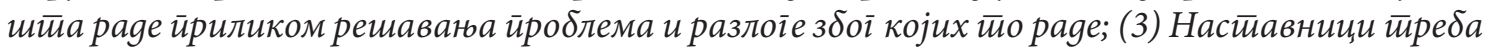

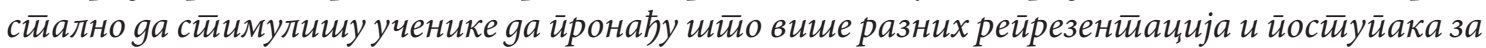
gобијаға некоі решена у свим майемайичким ироблемима са којима се сусрећу (на йример,

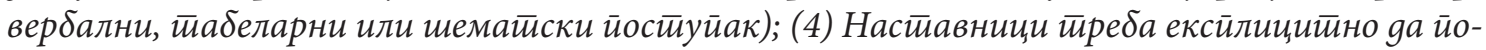
кажу ученицима битине разлике између сликовите и шемайске рейрезенитације ироблемске

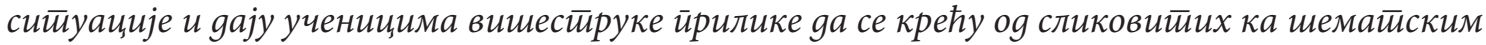

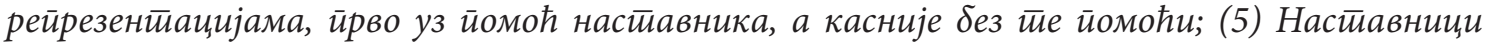
йреба gа йокажу ученицима важности узимана у обзир јеgиница физичких величина у решавану ирроблема који су иовезани са физиком.

Кльучне речи: заgатиак о йжжу који се иенье, Фибоначијева іррешка, решаване матиема-

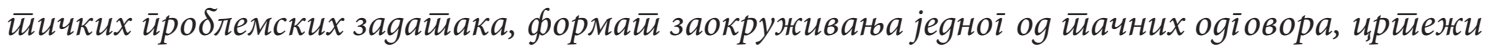

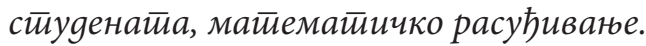

